\title{
The soluble guanylyl cyclase stimulator BAY 41- 2272 increases differentiation and function of brown adipocytes
}

\author{
Jennifer Etzrodt ${ }^{1 *}$, Linda S Hoffmann ${ }^{1}$, Andreas Friebe ${ }^{2}$, Alexander Pfeifer ${ }^{1}$ \\ From 6th International Conference on cGMP: Generators, Effectors and Therapeutic Implications \\ Erfurt, Germany. 28-30 June 2013
}

\section{Background}

There are two types of adipose tissue. White adipose tissue (WAT) stores energy in the form of lipids. Brown adipose tissue (BAT) consumes energy to produce heat by thermogenesis, which depends on the brown adipocytes specific marker uncoupling protein-1 (UCP-1). Metabolically active BAT is present in adult humans and its energy consuming properties could be exploited to increase energy expenditure. We and others showed that the nitric oxide (NO)/ cyclic guanosine monophosphate (cGMP) pathway is crucial for brown adipocyte differentiation [1,2]. Here we studied the role of sGC in brown adipocyte differentiation employing the sGC stimulator BAY 41-2272.

\section{Material and methods}

Mesenchymal stem cells isolated from BAT of newborn mice were differentiated into brown adipocytes in vitro using established protocols [1]. During differentiation, cells were incubated with $3 \mu \mathrm{M}$ BAY 41-2272, $200 \mu \mathrm{M} 8$ pCPT-cGMP or $30 \mu \mathrm{M}$ ODQ. Accumulated intracellular lipids were assessed by RedO staining and measurement of triglyceride (TG) content. To investigate the adipogenic program, Western Blot analysis of PPAR $\gamma, \mathrm{C} / \mathrm{EBP} \alpha$ and AP2 was performed. Thermogenic differentiation of the cells was determined by protein expression analysis of Cytc and gene expression analysis of thermogenic markers $U C P-1$, Cidea and $P G C-1 \alpha$.

\section{Results}

BAY 41-2272 increased lipid accumulation as determined by RedO staining and TG content (1,44-fold)

\footnotetext{
* Correspondence: etzrodt@uni-bonn.de

'Institute for Pharmacology and Toxicology, University of Bonn, 53105 Bonn, Germany

Full list of author information is available at the end of the article
}

compared to control. Protein expression of the adipogenic marker proteins PPAR $\gamma$ (1,4-fold), C/EBP $\alpha$ (1,5-fold) and AP2 (1,6-fold) were increased after BAY 41-2272 incubation compared to control. Adipogenic markers PPAR $\gamma$ (2,3-fold), C/EBP $\alpha$ (1,8-fold) and AP2 (2,1-fold) were increased after cGMP incubation compared to control. In contrast, inhibition of sGC by ODQ decreased protein expression of PPAR $\gamma$ (50\%), C/EBP $\alpha$ (29\%) and AP2 (51\%). The thermogenic marker genes UCP-1 (5,38-fold), Cidea (2,44-fold) and PGC-1 $\alpha$ (2,26fold) increased upon incubation with BAY 41-2272 compared to control. cGMP increased RNA levels of thermogenic markers $U C P-1$ (3,36-fold), Cidea (2,5fold) and $P G C-1 \alpha$ (2,50 fold). ODQ decreased the expression of $U C P-1$ (64\%), Cidea (74\%) and PGC-1 $\alpha$ (44\%). Protein expression of the mitochondrial marker Cytc was increased upon incubation with BAY 41-2272 (1,6-fold) and cGMP (1,77-fold). Protein expression of Cytc was lower in brown adipocytes incubated with ODQ (49\%).

\section{Conclusion}

Taken together, the results show that the sGC stimulator BAY 41-2272 increases the adipogenic and thermogenic program of brown adipocytes to a similar extent as the cGMP analogue. This hints to a therapeutic potential of BAY 41-2272. Its beneficial effect on adipogenesis and thermogenesis could lead to increased energy expenditure and could combat overweight and obesity.

\footnotetext{
Authors' details

${ }^{1}$ Institute for Pharmacology and Toxicology, University of Bonn, 53105 Bonn, Germany. ${ }^{2}$ Physiologisches Institut, University of Würzburg, 97070 Würzburg, Germany.
} 
Published: 29 August 2013

\section{References}

1. Haas B, Mayer P, Jennissen K, Scholz D, Berriel Diaz M, Bloch W, Herzig S, Fässle R, Pfeifer A: Protein kinase $G$ controls brown fat cell differentiation and mitochondrial biogenesis. Sci Signal 2009, 2:ra78.

2. Nisoli E, Clement E, Tonello C, Sciorati C, Briscini L, Carruba MO: Effects of nitric oxide on proliferation and differentiation of rat brown adipocytes in primary cultures. Br J Pharmacol 1998, 125:888-894.

doi:10.1186/2050-6511-14-S1-P20

Cite this article as: Etzrodt et al:: The soluble guanylyl cyclase stimulator BAY 41-2272 increases differentiation and function of brown

adipocytes. BMC Pharmacology and Toxicology 2013 14(Suppl 1):P20.

Submit your next manuscript to BioMed Central and take full advantage of:

- Convenient online submission

- Thorough peer review

- No space constraints or color figure charges

- Immediate publication on acceptance

- Inclusion in PubMed, CAS, Scopus and Google Scholar

- Research which is freely available for redistribution

Submit your manuscript at www.biomedcentral.com/submit 